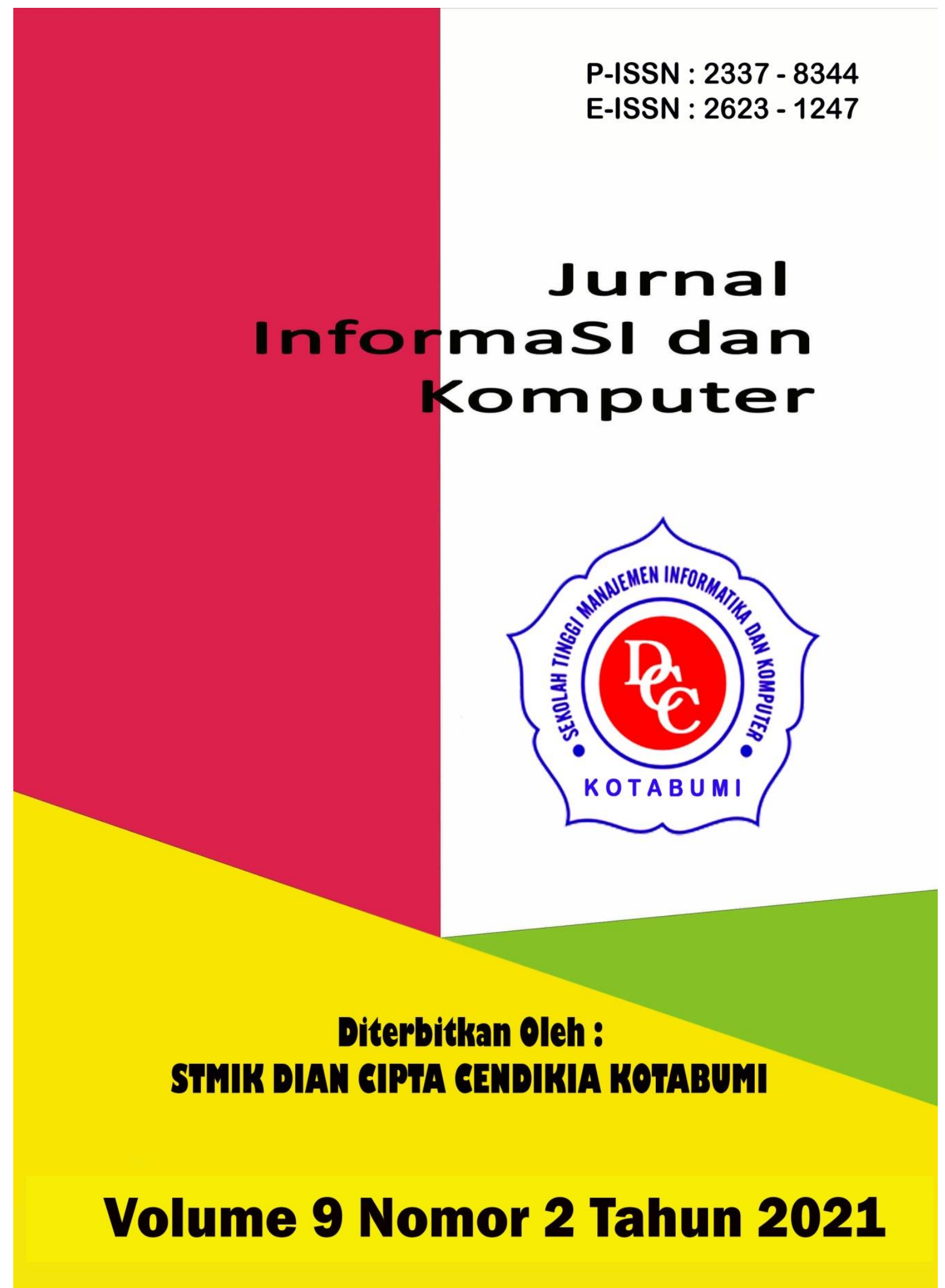




\section{Penerbit}

\section{Lembaga Penelitian STMIK Dian Cipta Cendikia Kotabumi}

Hak atas naskahh/tulisan tetap berada pada penulis, isi diluar tangung jawab penerbit dan Dewan Penyunting 


\section{PENGANTAR REDAKSI}

Puji syukur dipanjatkan kehadirat Tuhan Yang Maha Esa, atas karunia dan limpahan rahmatNYA jualah Jurnal Informasi dan komputer (JIK) STMIK Dian Cipta Cendikia Kotabumi ini dapat terwujud.Jurnal Informasi dan Komputer (JIK) yang terbit dua (2) kali dalam setahun ini merupakan suatu wadah untuk penyebar luasan hasil-hasil penelitian, studi pustaka, karya ilmiah yang berkaitan dengan Informasi dan Komputer khususnya bagi dosen-dosen STMIK Dian Cipta Cendikia Kotabumi serta umumnya para cendikiawan, praktisi, peneliti ilmu Informatika dan Komputer.

Harapan, dengan diterbitkannya Jurnal Informasi dan Komputer (JIK) ini sebagai salah satu bentuk sumbangan pemikiran dalam pengembangan ilmu informatika dan komputer yang berkaitan dengan kajian-kajian di bidang tekhnologi Informatik, Komunikasi Data dan Jaringan Komputer, perancangan dan Rekayasa Perangkat Lunak, serta ilmu-ilmu yang terkait dengan bidang Informasi dan Komputer lainnya.

Berkenaan dengan harapan tersebut, kepada para peneliti, dosen dan praktisi yang memiliki hasil-hasil penelitian, kajian pustaka, karya ilmiah dalam bidang tersebut diatas, dengan bangga redaksi Jurnal Informasi dan Komputer (JIK) menerima naskah ringkasan untuk dimuat pada jurnal Informasi dan Komputer (JIK) STMIK Dian Cipta Cendikia Kotabumi dengan berpedoman pada penulisan naskah jurnal sebagaimana dilampirkan pada halaman belakang (Bagian kulit dalam) buku jurnal ini.

Mutu dari suatu jurnal ilmiah tidak hanya ditentukan oleh para pengelolanya saja, tetapi para penulis dan pembaca jualah yang mempunyai peranan besar dalam meningkatkan mutu jurnal Informatika dan Komputer ini. Merujuk pada realita ini kamu sangat mengharapkan peran aktif dari peneliti untuk bersama-sama menjaga dan memelihara keberlangsungan dari jurnal Informasi dan Komputer STMIK Dian Cipta Cendikia Kotabumi ini. Yang juga tidak kalah pentingnya dari partisipasi tersebut diatas, adalah saran dan kritik yang membangun dari pembaca yang budiman agar kiranya dapat disampaikan langsung kepada redaksi JIK. Saran dan kritik yang membangun akan dijadikan masukan dan pertimbangan yang sangat berarti guna peningkatan mutu dan kualitas Jurnal Informasi dan Komputer STMIK Dian Cipta Cendikia Kotabumi.

Tak lupa diucapkan terima kasih yang tak terhingga atas perhatian dan kerjasama dari semua pihak yang tak dapat disebutkan satu persatu hingga dapat diterbitkan nya Jurnal Informasi dan Komputer (JIK) STMIK Dian Cipta Cendikia Kotabumi. Semoga apa yang telah diperbuat untuk kebaikan akan menjadi amal ibadah, amin.

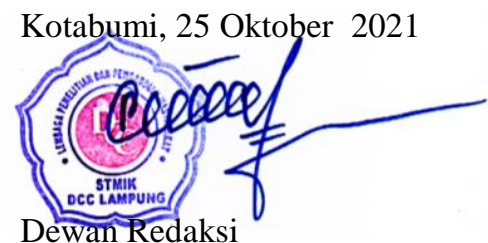




\section{JURNAL INFORMASI DAN KOMPUTER}

Volume 9 Nomor 2 Oktober 2021

Jurnal Informasi dan Komputer merupakan Sarana informasi ilmu pengetahuan, Tekhnologi dan Komunikasi yang berupa hasil penelitian, tulisan ilmiah, Ataupun studi pustaka. Jurnal ini terbit dua kali setahun pada bulan April dan Oktober. Berisi hasil penelitian ilmiah di bidang informatika yang bertujuan untuk menghubungkan adanya kesenjangan antar kemajuan teknologi dan hasil penelitian. Jurnal ini di terbitkan pertama kali pada tahun 2013.

Penanggung Jawab:

Ketua STMIK Dian Cipta Cendikia Kotabumi

\section{Pembina:}

Ketua STMIK Dian Cipta Cendikia Kotabumi Ketua Lembaga Penelitian STMIK Dian Cipta Cendikia Kotabumi

\section{Pimpinan Redaksi}

Dwi Marisa Efendi,.S.Kom.,M.Ti

\section{Redaksi pelaksana}

Rustam,.S.Kom,.M.Ti (STMIK Dian Cipta Cendikia Kotabumi)

Nurmayanti M.Kom (STMIK Dian Cipta Cendikia Kotabumi)

Sukatmi,.S.Kom., M.Kom (AMIK DCC Bandar Lampung)

Sampurna Dadi Riskiono,M.Kom (Universitas Teknokrat Indonesia)

Ifo Wahyu Pratama,S.Kom.,M.Ti(AMIK MASTER Lampung)

\section{Mitra Bestari}

Dr. RZ. ABDUL AZIZ, ST., MT (Institut Informatika dan Bisnis Darmajaya)

Dr. Dadang Sudrajat, S.Si, M.Kom (STMIK IKMI Cirebon)

Dr. Septafiansyah Dwi Putra, S.T., M.T (Politeknik Negeri Lampung)

Dr. Evi Grativiani, S.E., M.S.I (Universitas Sebelas Maret)

Rohmat Indra Borman ( Universitas Teknokrat Indonesia )

Ferry Wongso, S.KOm., M.Kom ( STMIK Darma Pala Riau)

Ferly Ardhy, S.Kom., M.Ti ( Universitas Aisyah Pringsewu )

Firmansyah, S.E., M.Si (STMIK Darma Pala Riau)
Amarudin (Universitas Teknokrat Indonesia)

Didi Susianto, S.T., M.Kom (AMIK Dian Cipta Cendika Bandar Lampung)

Alhibarsyah, St., M.Kom (STMIK Tunas

Bangsa Bandar Lampung)

Kemal Farouq Mauladi, S.Kom .M.Kom (Universitas Islam Lamongan)

Rima Mawarni, M.Kom ( STMIK Dian Cipta Cendikia Kotabumi)

Wira Jaya Hartono, S.Pd., M.Pd ( STMIK Darma Pala Riau)

Penerbit : STMIK Dian Cipta Cendikia Kotabumi Bekerja Sama Dengan LPPM STMIK Dian Cipta Cendikia Kotabumi.

\section{Alamat Redaksi/Penerbit:}

Jl. Negara No. 3 Candimas Kotabumi Lampung Utara

No Telpon/Fax 072423003

Email : 1ppm-stmik@dcc.ac.id 


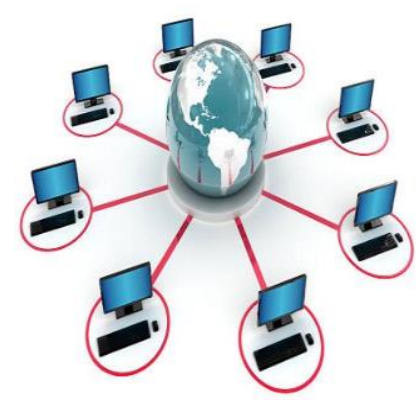

\section{JURNAL INFORMASI DAN KOMPUTER VOL. 9 NO. 2 THN. 2021}

\section{DAFTAR ISI}

Halaman

Sistem Informasi Akuntansi Persedian Barang Berbasis Web Pada Lembaga

Permasyarakatan Kelas II A Banceuy Bandung : "Kelompok Tani Desa Banjar Kertarahayu" Teuku Rian Hardiyansyah, Fatia Salsa Azzahra (Politeknik Piksi Ganesha Bandung ${ }^{1,2}$ )

Penerapan Finite State Automata Pada Vending Machine Penjual Obat Non Resep

Dokter Dan Keperluan Medis

Eko Supriyanto $^{1}$, Angga Ardiansyah ${ }^{2}$, Frieyadie $^{3}$, Sri Rahayu ${ }^{4}$, Windu Gata ${ }^{5}$

(Universitas Nusa Mandiri ${ }^{12}$ )

Sistem Pendukung Keputusan Untuk Menentukan Kelayakan Pengajuan Sertifikasi Guru Dengan Metode Simple Additive Weighting (Studi Kasus : Ma Al Muhajirin Janti Jogoroto Jombang)

Budiman, umam baharudin, winarti

(Universitas Darul 'Ulum Jombang)

Perancangan Infrastruktur Domain Name Server Lokal Menggunakan Ubuntu Server 16.04

Pada PT. Xyz

Zaenal Mutaqin Subekti, Hendra Setiawan, Satria, Widia Murni Wijaya,

Aliy Hafiz, Warsudi

(STMIK Bani Saleh, Universitas Negeri Yogyakarta, AMIK Dian Cipta Cendikia,

STMIK MIC CIkarang)

Perancangan Sistem Informasi Idea Proposal (Ip) Berbasis Web Pada Pt. Paxel Algorita Unggul

Julian Murhan Sahputra, Indah Purnamasari

(Universitas Nusa Mandiri ${ }^{12}$ )

Sistem Pendukung Keputusan Untuk Menentukan Ekstrakurikuler Atletik

Berdasarkan Bakat Siswa Menggunakan Metode Profile Matching

Agnes Basuki, Petrus Sokibi, Tiara Eka Putri

(Universitas Catur Insan Cendekia)

Penerapan Algoritma K-Means Untuk Pengelompokan Usia Calon Penerima Vaksin

Di Kab. Ngawi

Irna Yuniarfi, Saifulloh

(Universitas PGRI Madiun $^{12}$ )

System Penilaian Seleksi Calon Karyawan Baru Menggunakan Metode Simple Additive Weighting (SAW) Di PT.TNA

Anik Sri Wahyuningsih, Yudhi Firmansyah

(Universitas Panca Sakti Bekasi ) 
Perancangan Sistem Informasi Pembayaran SPP Menggunakan Framework Laravel Ichwan Habib Moudi

(Universitas Panca Sakti Bekasi)

Implementasi Algoritma K-Means Dan Algoritma Apriori Optimasi Kinerja Ecu

(Study Kasus Mobil Avanza Dan Xenia)

Sigit Mintoro' Asep Afandi

(STMIK Dian Cipta Cendikia Kotabumi)

Sistem Pakar Penyakit Buah Kakao Untuk Peningkatan Hasil Panen Kakao Menggunakan

Metode Case Base Reasoning (CBR) Berbasis Web Mobile

Aliy hafiz, Verawati

(AMIK Dian Cipta Cendikia,Bandar Lampung)

Penerapan Metode Rapid Application Develomment (RAD) Dalam Pengembangan

Sistem Pemesanan Menu Berbasis Android

Aris Baihaqi, Tumini

(Fakultas Sains dan Teknologi ${ }^{1,2}$ )

Rancang Bangun Sistem Informasi Geografis Pariwisata Di Lampung Timur

Sukatmi, Rexa Alfa Rizi

(AMIK DCC Bandar Lampung ${ }^{12}$ )

Implementasi Psak No. 45 Pada Proses Penyusunan Laporan Keuangan Menggunakan

M.S. Excel Dan Aplikasi Accurate Accouting Pada STMIK Bani Saleh

Marhakim, Willy Adam

(STMIK Bani Saleh ${ }^{12}$ )

Sistem Prediksi Harga KOPI LAMBAR ( Lampung Barat) Dengan Metode

Backpropagation, dan Double Exponential ( Studi Kasus BUMDES )

Supriyanto, Dwi marisa Efendi,Rhomadhon

(STMIK Dian Cipta cendikia Kotabumi ${ }^{1-}$ )

Sistem Informasi Pemasaran Produk Umkm Berbasis Web Pada Kecamatan Bumi

Nabung Lampung Tengah

Yuli Syafitri, Agus Prasetyo, Reni Astika

(AMIK Dian Cipta Cendikia Bandar Lampung)

Rancang Bangun Aplikasi Pembelajaran Aksara Lampung Berbasis Android

Ferly Ardhy, Hendra Syahrobi

(Universitas Aisyah Pringewu ${ }^{1,}$ STMIK Dian Cipta Cendikia ${ }^{2}$ )

Sistem Pakar Diagnosa Penyakit Kulit Pada Balita Menggunakan Metode Naïve

Bayes Dan Forward Chaining Studi Kasus Puskesmas Cempaka Sungkai Selatan

Sidik Rahmatullah, Rima Mawarni

(STMIK Dian Cipta Cendikia Kotabumi ${ }^{12}$ )

Rekayasa Perangkat Lunak Perhitungan Harga Pokok Produksi Metode

Full Costing Pada Umkm Mitra Cake Di Bandar Lampung

Pitrawati, Arif Sanjaya

(AMIK Dian Cipta Cendikia, Bandar Lampung) 
Rancang Bangun Sistem Ujian Online Menggunakan Algoritma Cosine Similarity

Berbasis Web

Haryono, Zaenal Mutaqin Subekti, Widiyawati, Hidayatullah

(STMIK Bani Saleh ${ }^{1234}$ )

Model Aplikasi Helpdesk Ticketing System Berbasis Web Menggunakan Metode Rad

Indra Permana

Pattern Recognition Tulisan Tangan Huruf Hijaiyah Menggunakan Metode

Convolutional Neural Network (CNN)

Mufassiril Abror, Nopiyanto

(Universitas Panca Sakti Bekasi ${ }^{12}$ )

Aplikasi Sistem Informasi Keuangan Berbasis Android Di Perumahan Taman

Karang Bahagia

Melda Ayulestari

(Universitas Panca Sakti Bekasi)

Audit Pelayanan Sistem Rujukan Online Puskesmas Menggunakan Framework COBIT 5.0

Nurmayanti, Merri Parida, Ngajiyanto, Ina Anzalna

(STMIK Dian Cipta Cendikia Kotabumi ${ }^{1234}$ )

Perancangan Sistem Informasi Pengolahan Data Nilai Siswa Berbasis Web

Erin Ermawati, Anik Sri Wahyuningsih

(Fakultas Sain dan Teknologi, Universitas Panca Sakti Bekasi ${ }^{12}$ )

Pengembangan Sistem Pelaporan Data Hasil Inspeksi Barang Berbasis Web

Siska Putriani

(Universitas Pancasakti Bekasi)

Penerapan Extreme Programming Dalam Perancangan Aplikasi Web Food Market

Tumini, Hilman Septiana

(Fakultas Sains dan Teknologi Universitas Panca Sakti Bekasi ${ }^{1,2}$ )

Sistem Pencarian Barang Berbasis Website Menggunakan Php Dan Mysql

Studi Kasus PT. Surya Technology Industri Sulaeman

(Universitas Panca Sakti Bekasi)

Implementasi Metode Prototype Pada Sistem Peminjaman Alat Kerja Berbasis Web

Di PT SK Metalindo

Ali Mulyanto, Arjun Gunawan

(Univeritas Panca Sakti Bekasi)

Aplikasi Tata Cara Wudhu Menggunakan Teknologi Augmented Reality

Sebagai Media Pembelajaran Di TK Al Fatih

Ahmad Yakub, Idarul Fadli

(Universitas Panca Sakti Bekasi ${ }^{12}$ )

Sistem Pakar Diagnosa Penyakit Ayam Petelur Menggunakan Metode Certainty Factor

Berbasis Web Mochammad

Taufiq Hidayat, Ali Mulyanto

(Universitas Panca Sakti Bekasi ${ }^{12}$ ) 
Penerapan Metode Prototyping Dalam Perhitungan Hasil Produksi Menggunakan

Arduino Uno R3 Dan Php Di PT. Indonesia Epson Industry

Amandha Aulia, Ajar Rohmanu

(Universitas Panca Sakti Bekasi ${ }^{12}$ )

System Pendukung Keputusan Penentuan Guru Teladan Dengan Metode Profile Matching

Hasbulloh, Agmawarnida

(Universitas Panca Sakti Bekasi ${ }^{1,2}$ )

Implementasi Waterfall Method Pada Aplikasi Buku Induk Siswa Berbasis Web

Idam Holid, Yogie Krisnayadi

(Universitas Panca Sakti ${ }^{12}$ )

Pengembangan Text To Speech Media Pembelajaran Untuk Pengenalan

Anggota Tubuh Manusia Kelas V Sekolah Dasar

Juwanda Saputra, Ali Mulianto

(Teknik Infomratika Fakulutas Sains dan Teknologi ${ }^{12}$ )

Perancangan Sistem Peminjaman Barang Berupa Aset Tetap Berbasis Web

Pada Lembaga Permasyarakatan Kelas II A Banceuy Bandung

Guntur Salasa Priambodo, Perwito, Candra Mecca Sufyana

(Politeknik Piksi Ganesha Bandung ${ }^{1,2,3}$ )

Metode Pemilihan Karyawan Terbaik Sebagai Penentu Goodwill Perguruan Tinggi

Dengan Menggunakan Metode Topsis (Studi Kasus Perguruan Tinggi Di Lampung Utara)

Dwi Sartika, Pakarti Riswanto

(STMIK Dian Cipta Cendikia Kotabumi)

Sistem Pendukung Keputusan Pemilihan Merek Smartphone Menggunakan

Metode Analytical Hierarchy Process (AHP)

Ade Kiki Fatmawati, Muhammad Sultan Raflie, Norma Yunita

(Universitas Nusa Mandiri ${ }^{123}$ )

Pattern Recognition Aksara Lampung Menggunakan Algoritma Neural Network

Metode Analytical Hierarchy Process (AHP)

Nopiyanto, Rahmadi

(Universitas Panca Sakti Bekasi) 


\title{
PENERAPAN EXTREME PROGRAMMING DALAM PERANCANGAN APLIKASI WEB FOOD MARKET
}

\author{
Tumini ${ }^{1}$, Hilman Septiana ${ }^{2}$ \\ Fakultas Sains dan Teknologi Universitas Panca Sakti Bekasi ${ }^{1,2}$ \\ Jl. Raya Hankam No. 54, Jatirahayu, Pondok Melati ${ }^{1,2}$ \\ E-mail : kemuningijo@gmail.com ${ }^{1}$, hilmanseptiana19@gmail.com²
}

\begin{abstract}
ABSTRAK
Bonjuk launchbox cafe adalah usaha bergerak pada bidang kuliner yang dalam operasionalnya masih menggunakan sistem manual. Supaya usaha dapat berkembang meningkat maka diperlukan sistem penyediaan layanan yang lebih efektif dan efisien dalam proses penjualannya. Tujuan penelitian dibangun sebuah aplikasi berbasis web yang bisa memroses penjualan makanan dengan cara praktis dan mudah, cepat, akurat dan handal. Perancangan aplikasi sistem penjualan berbasis web ini dibangun menggunakan konsep data model yaitu ERD (Entity Relationship Diagram), bahasa pemrograman PHP dan MySql dengan Framework Laravel, React Native untuk database peyimpanan serta dijalankan pada sistem operasi Windows 7 atau versi Windows yang lebih tinggi. Hasil akhir dari perancangan yaitu aplikasi penjualan food market dengan pemodelan terstruktur agar data masukan akan diolah dengan sistem manajemen database yang lebih baik sehingga memberikan kemudahan, ketepatan perhitungan, ketelitian, kecepatan proses pelaporan serta memperkecil kesalahan yang dapat terjadi karena sistem yang baru sudah terstruktur dan rapi.
\end{abstract}

Kata kunci : system pemesanan, penjualan, aplikasi web, laravel.

\section{ABSTRACTS}

Bonjuk launchbox cafe is a business engaged in the culinary field that still uses paper documents in the sales process or has not been computerized. In order for businesses to develop and increase, a more effective and efficient service provision system is needed in the sales process. The purpose of the research is to build a web-based application that can process food sales in a more practical, fast, accurate and reliable way. The design of this web-based sales system application is built using the concept of a data model, namely ERD (Entity Relationship Diagram), PHP and MySql with Laravel Framework, React Native programming languages for database storage and is run on the Windows 7 operating system or higher version of Windows. The final result of the design is a food market sales application with structured modeling so that the input data will be processed with a better database management system so as to provide convenience, accuracy of calculations, accuracy, speed of the reporting process and minimize errors that can occur because the new system is structured and neat.

Keywords: contains a maximum of 5 important words in the study.

\section{PENDAhuluan}

Di era sekarang ini, semua aktifitas sudah menggunakan fitur digital yang sangat canggih. Mulai dari belanja berbagai pernak-pernik, perlengkapan olahraga dan eksterior rumah, hingga memesan moda transportasi dan memesan makanan, semuanya dilakukan secara online. Ponsel menjadi satu-satunya alat digital yang dianggap sangat pintar, layaknya Kebutuhan di masa depan. Semua hal di dunia ini bisa diakses hanya dalam satu genggaman ponsel, yang tentunya terhubung ke jaringan internet. Data penjualan Bonjuk lainchebox cafe masih menggunakan dokumen-dokumen kertas yang menumpuk karena tidak langsung diproses sehingga membutuhkan tempat untuk dokumen kertas yang tertumpuk dan hilangnya dokumen. Pengolahan data penjualan pada perusahaan belum terkomputerisasi dengan baik. Sehingga menimbulkan kesulitan pada saat mencari data, seperti data pesanan pelanggan, data transaksi penjualan dan data laporan. Untuk itu perlu dirancang sebuah sistem penjualan Food Marketa secara online pada Cafe. Penelitian ini bertujuan untuk menciptakan sebuah aplikasi berbasis web dengan menggunakan metode Extreme 
Programming (XP) merupakan pendekatan yang berfokus pada coding yang merupakan aktivitas utama pada semua tahapan atau siklus pengembangan sistem[1]

\section{METODE PENELITIAN}

Dalam mengembangkan perangkat lunak ada banyak pilihan pendekatan atau metode yang digunakan, Dalam peneltian kali ini akan digunakan dalah Extreme Programming untuk membuat aplikasi Food Market. Extreme Programming (XP) merupakan sebuah proses rekayasa perangkat lunak yang cenderung menggunakan pendekatan berorientasi objek dan sasaran dari metode ini adalah tim yang dibentuk dalam skala kecil sampai medium serta metode ini juga sesuai jika tim dihadapkan dengan requirement yang tidak jelas maupun terjadi perubahan-perubahan requirement yang sangat cepat [2].

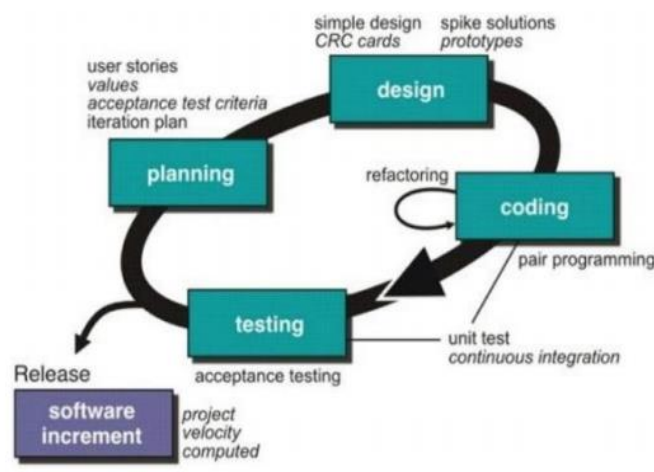

Gambar 1. Tahapan XP

\section{Planning (Perencanaan)}

Tahapan ini dimulai dengan wawancara Apa saja kebutuhan aktifitas suatu sistem tujuannya pengguna memahami proses transaksi untuk sistem dan mendapatkan gambaran yang jelas mengenai fitur utama, desain maupun fungsi dan hasil yang diinginkan. Dalam pembangunan aplikasi Food market pada tahapan ini dimulai dari mengidentifikasi apa saja yang timbul berupa permasalahan yang terjadi pada sistem yang sedang berjalan, Tidak hanya itu, pada tahap planning juga memuat tahapan dimana developer menentukan fungsionalitas keseluruhan dari software yang akan dikembangkan [3]

\section{Design (Perancangan)}

Pada tahapan perancangan melalakukan pembuatan pemodelan sistem dari hasil analisa kebutuhan yang diperlukan. Dalam pemodelan terdapat juga basis data Untuk menghubungkan antar data.

Pemodelan sistem yang akan digunakan yaitu Unified Modelling Language (UML). UML adalah bahasa visual untuk memodelkan dan menggmbarkan komunikasi sebuah sistem dengan mempergunakan diagram[4] dan juga terdiri dari beberapa diagram antara lain Activity, Use-Case Diagram, Diagram, Deployment Diagram dan Component Diagram.entity Relationship Diagram (ERD) dan Logical Record Structure (LRS) Akan digunakan untuk pemodelan basis data.

\section{Coding (Pengkodean)}

Coding atau pengkodean adalah tahapan dimana rancangan yang telah dibuat kemudian diimplementasikan kedalam bentuk bahasa pemrograman yang dapat dikenali oleh komputer[5].

pada tahapan ini akan dilakukan implementasi dari perancangan sistem yang telah dibuat sebelumnya dan akan dibuatkan berupa kode program menghasilkan prototipe dari perankat lunak pengkodean. dalam membangun apliksi android dan web Food Market menggunakan bahasa pemograman Hypertext Preprocessor(PHP) dan Framewrok Berupa Laravel dan React Native yang di padukan dengan Javascript, Hypertext Markup Language(HTML) dan Cascading Style Sheets (CSS). Untuk Basis data, DBMS (Database Managament System) yang digunakan adalah MySQL.

\section{Testing (Pengujian)}

Pengujian atau testing menggunakan pendekatan black box testing. Pengujian kotak hitam atau black box testing merupakan software testing yang menguji pada spesifikasi fungsional untuk mengetahui apakah fitur, input dan output dari software telah sesuai spesifikasi telah ditetapkan [6].

Pada Tahapan pengujian akan dilakukan terhadap aplikasi yang sudah dikembangkan atau di bangun pada tahapan ini akan diuji dari 
keseluruhan sistem berupa fitur dan fungsionalitas kemudian akan ditinjau ulang. Metode yang akan digunakan pengujian untuk aplikasi Food Market adalah Black-box, pengujian akan fokus terhadap kinerja yang dihasilkan sistem yaitu masukan dan keluaran.

\section{Software Increment (Peningkatan Perangkat Lunak.}

Tahapan ini tahap memperbarui pengembangan sistem yang sudah di buat secara bertahap untuk hasil yang lebih baik dengan menambahkan berupa fitur atau kontendan juga mengubah tampilan lebih elegan dan menarik.

\section{HASIL DAN PEMBAHASAN}

\subsection{Planning (Perencanaan)}

\subsubsection{Identifikasi Permasalahan.}

Permasalahan yang timbul saat ini adalah belum adanya sistem yang dapat digunakan untuk melakukan penjualan dan pemesanan makanan. Penyebaran informasi terkait penjualan makanan masih kurang optimal karena masih dilakukan dengan cara manual.

\subsubsection{Analisa Kebutuhan.}

Analisa kebutuhan untuk system pemesanan makanan ini direncanakan sebagai berikut :

a. Calon pembeli dapat melihat informasi harga dan jenis makanan.

b. Calon pembeli dapat melakukan pendaftaran di aplikasi.

c. Calon pembeli dapat login.

d. Calon pembeli dapat melakukan pemesan

e. Calon pembeli dapat melakukan verifikasi data diri.

f. Admin dapat login.

g. Admin dapat manajemen data periode.

h. Admin dapat manajemen data makanan.

i. Admin dapat manajemen data harga.

j. Admin dapat menajemen data pembeli.

\subsection{Design (Perancangan)}

\subsubsection{Pemodelan Sistem}

Dari analisa kebutuhan yang sudah dibuat, maka dihasilkan desain system menggunakan UML dengan hasil sebagai berikut :

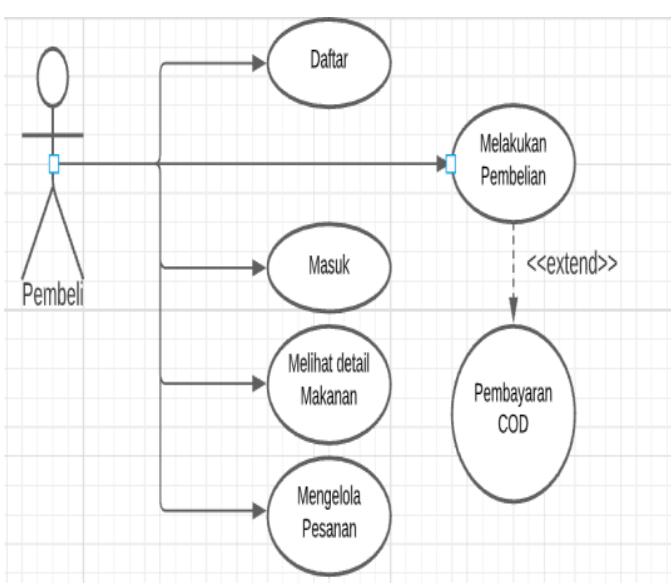

Gambar 2. Use case diagram calon peserta

Diagram diatas menggambarkan mengenai fungsi dari aplikasi Food market yang dapat digunakan oleh calon pembeli, dimana calon pembeli dapat melihat informasi pendaftaran, melakukan pendaftaran, masuk ke form register dan mengisi form yang disediakan

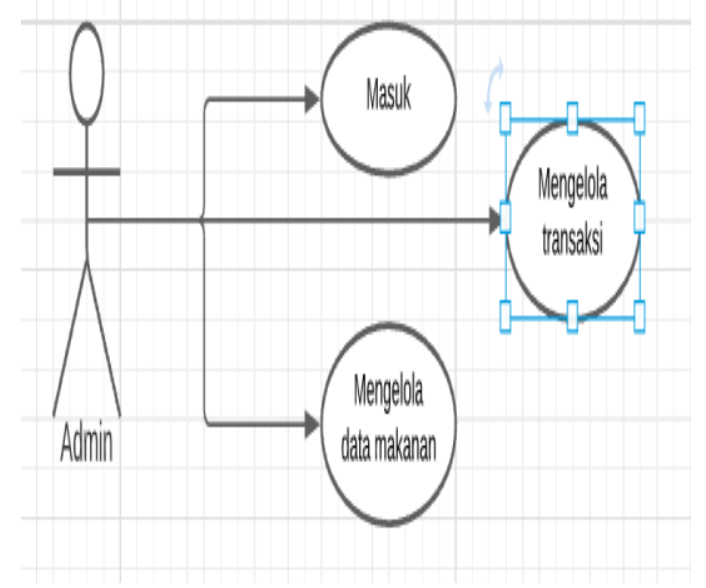

Gambar 3. Use case diagram admin

Use Case diagram admin menggambarkan hak akses apa saja yang bisa digunakan dari aplikasi Food market untuk mendapatkan hak akses admin di haruskan login, jika berhasil maka akan dialihkan ke halaman administrator, admin bisa melakukan pengolahan data pembeli atau user, data harga,data makanan. 


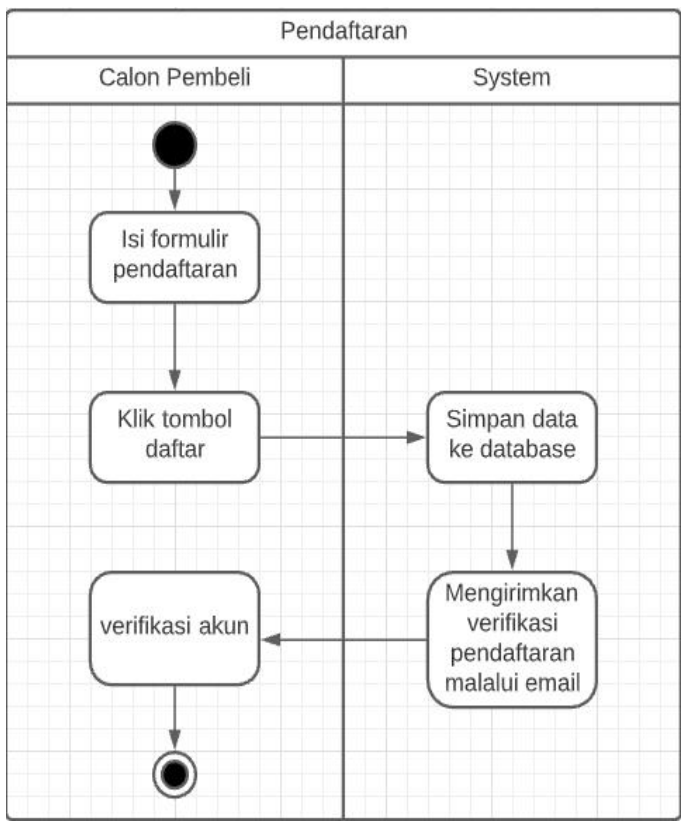

Gambar 4. Activity diagram pendaftaran

Calon pemebeli atau user ingin maelakukan pendaftaran untuk membuka menu pendaftaran kemuadian akan menampilkan menu pendaftaran yang di haruskan mengisi data, kemudian jika sudah lengkap mengisi data yang diminta maka klik submit untuk menyimpan data tersebut ke database.

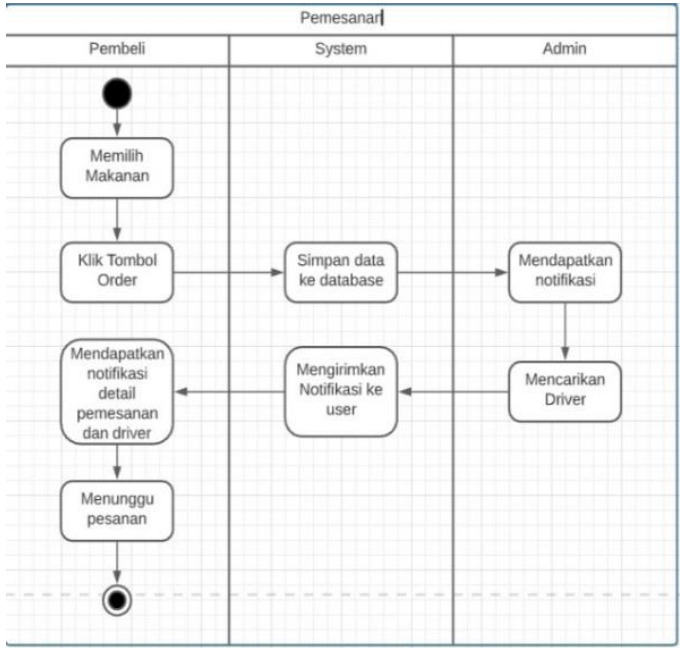

Gambar 5. Activity diagram pemesan makanan

Untuk bisa melakukan pemesanan makanan di dalam aplikasi, user login dahulu dan masuk ke menu home akan di tampilkan deskripsi dan gambar makanan kemudian pilih makanan sesusai keinginan dan klik order now.

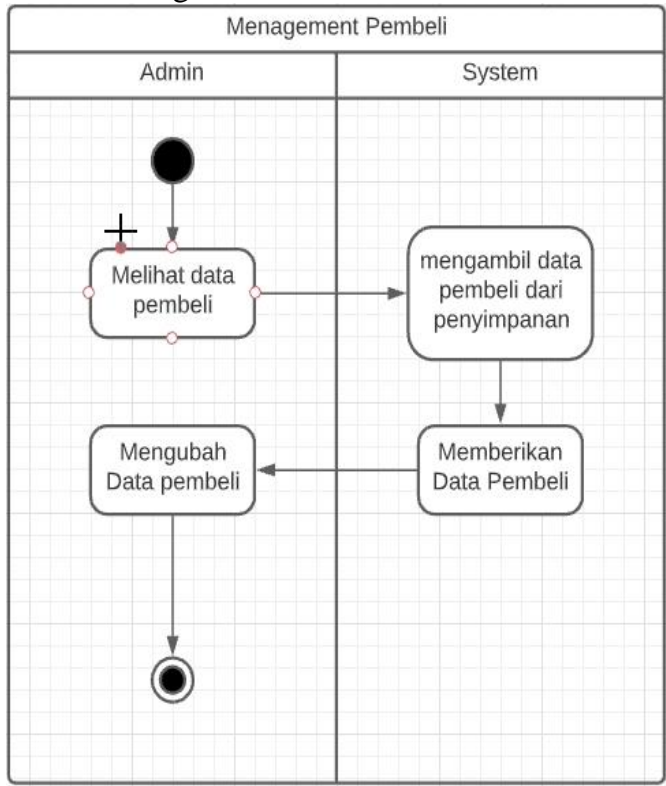

Gambar 6. Activity diagram manajemen data pembeli

Untuk melakukan pengolahan data pembeli, administrator memlih halaman menu user maka sistem akan menampilkan data user. Kemudian pilih data user yang ingin dilihat maka sistem akan menampilkan data detail user tersebut dan status user.

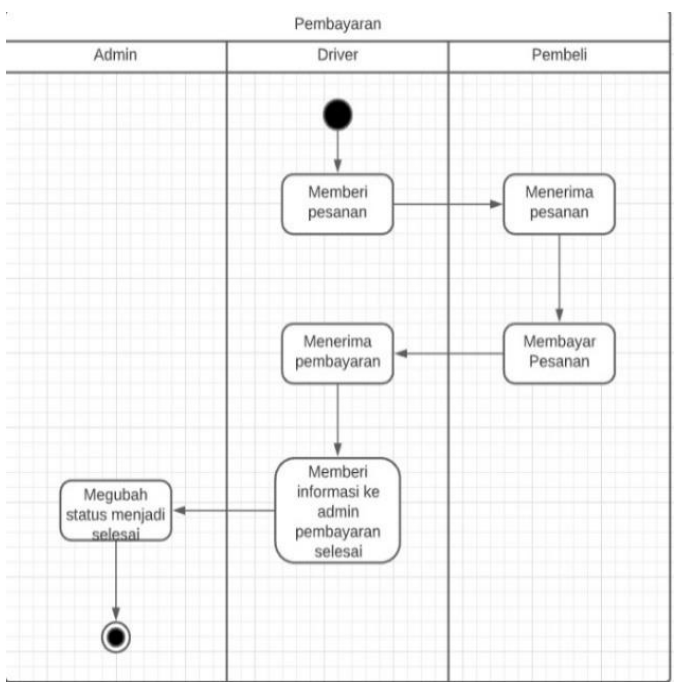

Gambar 7. Activity Diagram manajemen Pembayaran

Untuk melakukan pengolahan data pembayaran admin harus membuka halaman transaksi disana admin bisa mengubah status pemesan pembeli, 
pembayaran disini masih menggunakan cara cash on delivery(COD). Setelah kurir menerima uang dari pembeli akan di infokan ke admin dan admin mengubah status menjadi selesai.

\subsubsection{Perancangan Arsitektur Sistem}

Perancangan arsitektur system digambarkan menggunakan component diagram dan deployment diagram. Untuk system pemesanan makanan ini, component diagram dan deployment diagram tergambar pada figure berikut.

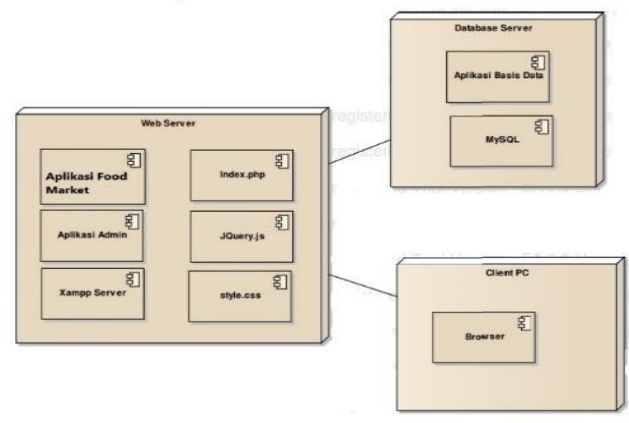

Gambar 8. Component diagram aplikasi Food market

Component Diagram diatas menggambarkan mengenai arsitektur aplikasi Food market berbasis web dimana terdapat dua pengguna yaitu aplikasi pembeli menggunakan React Native dan aplikasi admin menggunakan Laravel. Kedua aplikasi tersebut minggunakan komponen yaitu Apache Service, Bahasa pemograman Javascript, PHP, CSS dan Jquery. Untuk basis data menggnakan PhpMyAdmin dengan sistem manajemen basis data yang digunakan adalah MySQL.

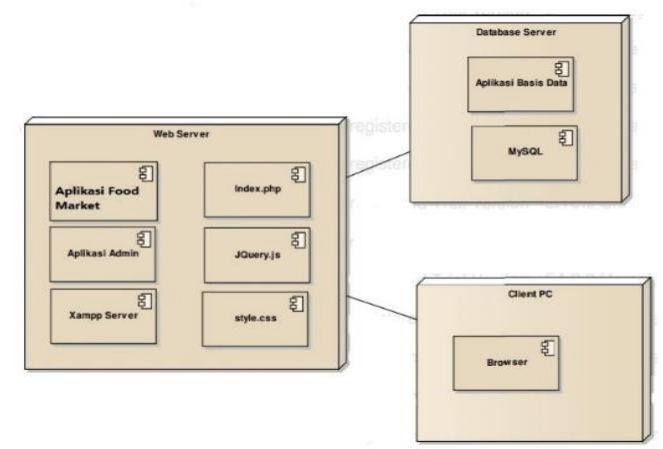

Gambar 9. Deployment diagram aplikasi Food market
Gambar diatas menggambarkan pemetaan perangkat lunak ke processing node. Bahwa aplikasi berbasis web dibagi 3 node yaitu web server yang didalamnya terdiri aplikasi pembeli dan aplikasi admin, Apache service, Javascript, PHP, CSS dan Jquery. Node ke dua yaitu client PC menjelaskan untuk penggunaan aplikasi ini dilakukan menggunakan web browser seperti Google chrome, microsoft edge, firefox dan lain-lain. Node yang ketiga adalah Database Server yang terdiri dari aplikasi basis data yaitu PhpMyAdmin dan sistem manajemen basis data menggunakan perangkat lunak MySQL.

\subsubsection{Pemodelan Basis Data}

Pemodelan basis pada pemelitian ini digambarkan menggunakan Entity Relationship Diagram(ERD) dan Logical Record Structure (LRS).

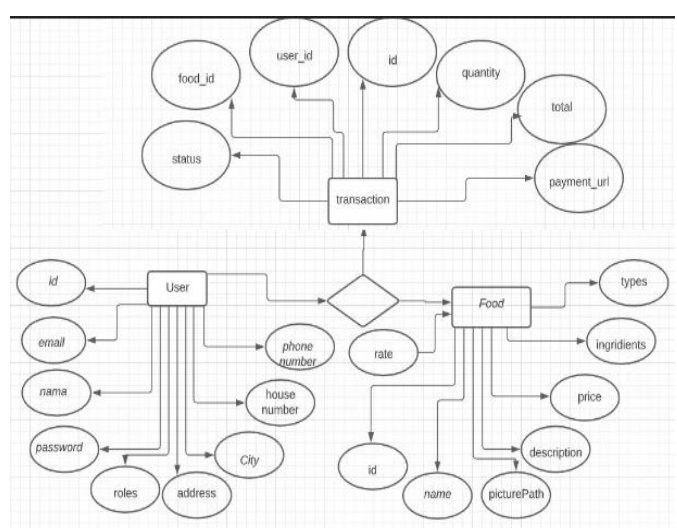

Gambar 9. Entity realtionship diagram aplikasi Food Market

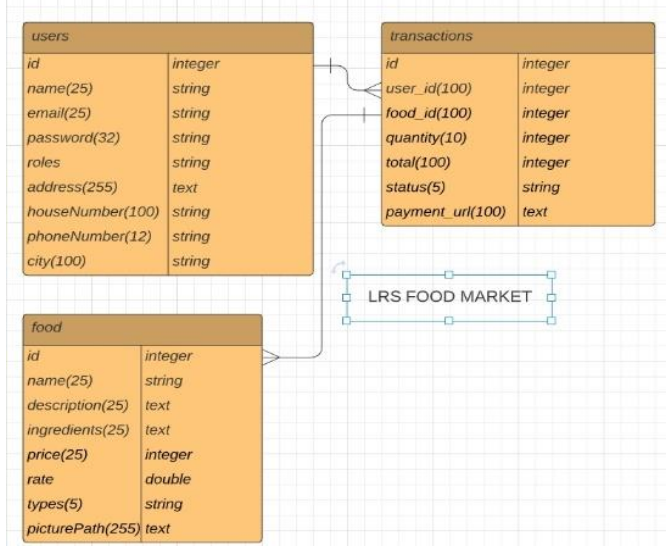

Gambar 10. Logical record structure aplikasi Food Market 


\subsection{Coding(Pengkodean)}

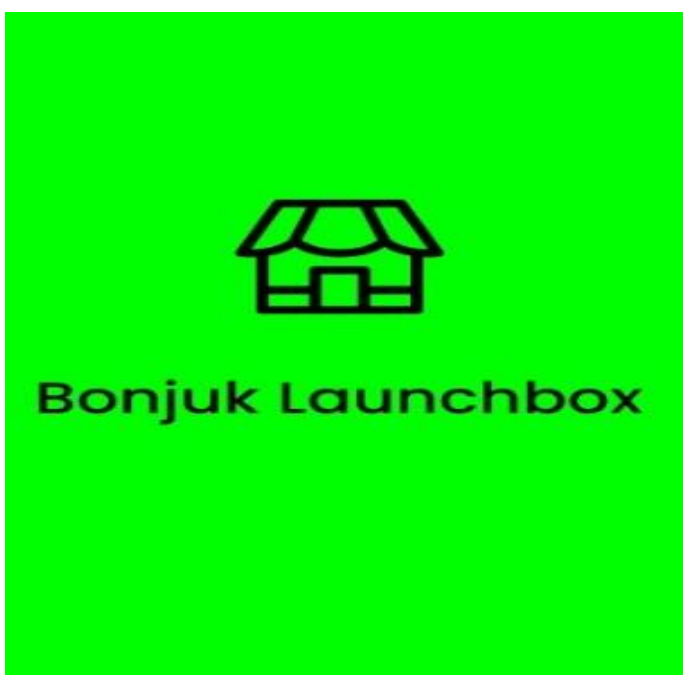

Gambar 11. Halaman Depan

Halaman Depan aplikasi Food Market hanya menalpilkan ikon untuk beberapa saat dan kemudian akan di alihkan ke halaman login.

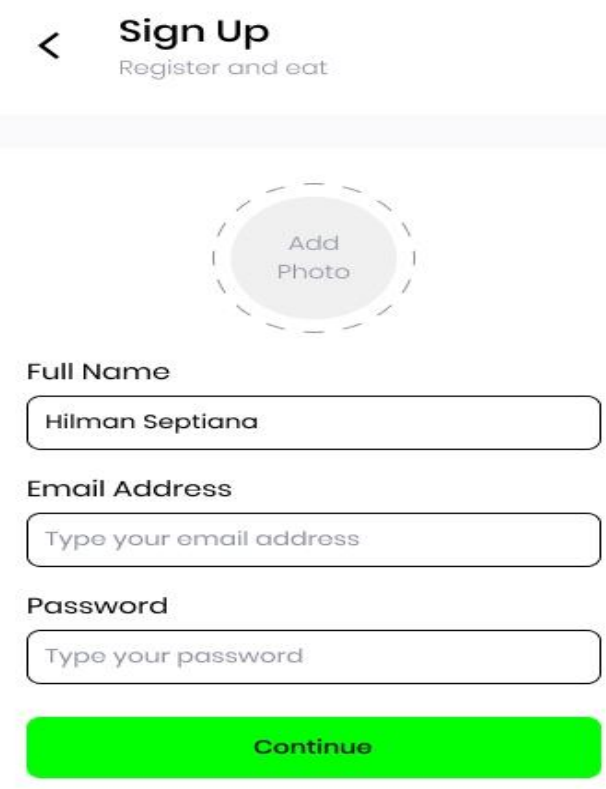

Gambar 12. Halaman Pendaftaran

Halaman pendaftaran digunakan oleh user untuk bisa menggunakan aplikasi.

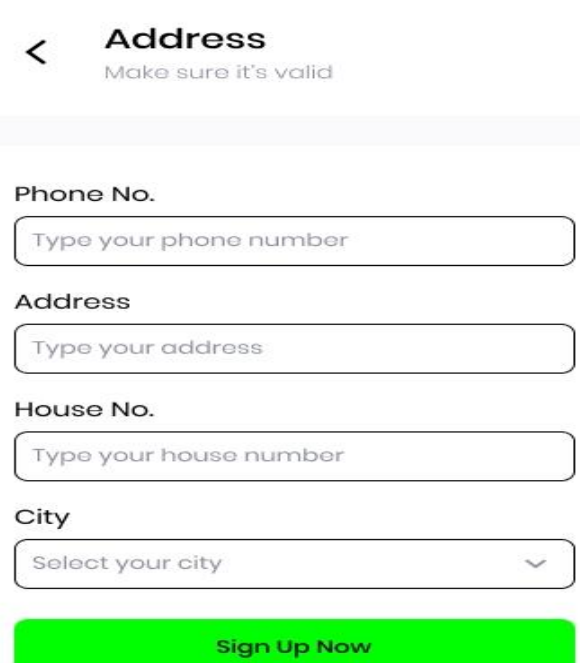

Gambar 13 Halaman Pendaftaran

Halaman ini adalah formulir daftar untuk calon pembeli sebelum masuk ke halaman home diharuskan untuk login terlebih dahulu

\section{Sign In}

Find your best ever meal

Email Address

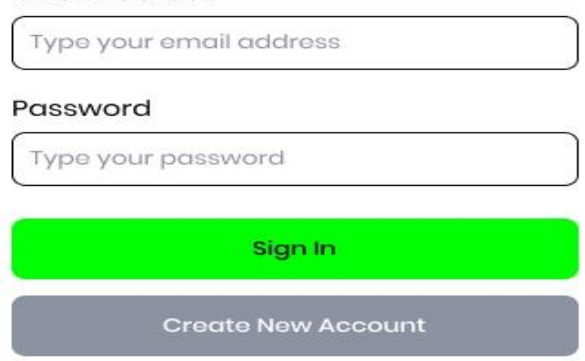

Gambar 13. Halaman Login

Halaman ini merupakan untuk login ke aplikasi dimana sebelumnya sudah melakukan pendaftaran. 


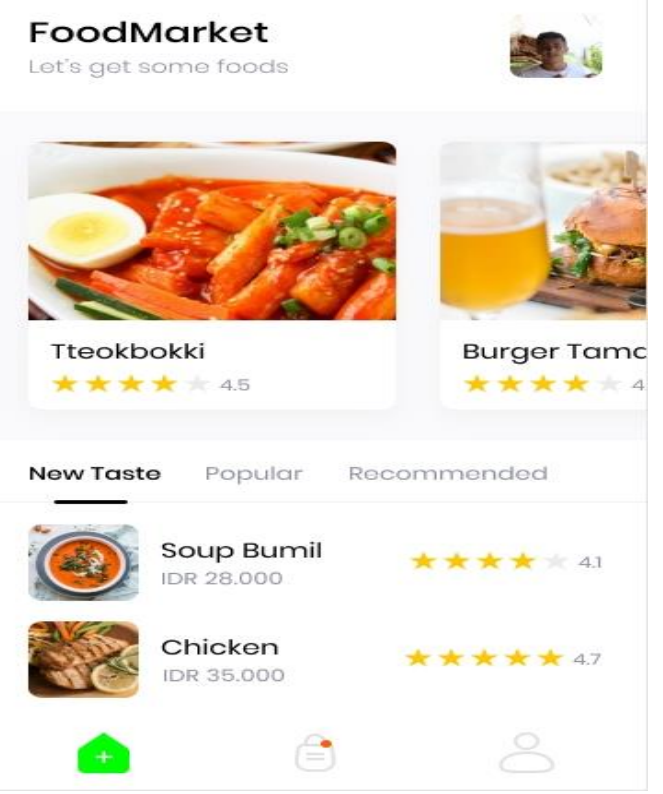

Gambar 14. Halaman Home

Halaman ini merupakan yang utama untuk pembeli untuk bisa memilih makanan untuk di beli.

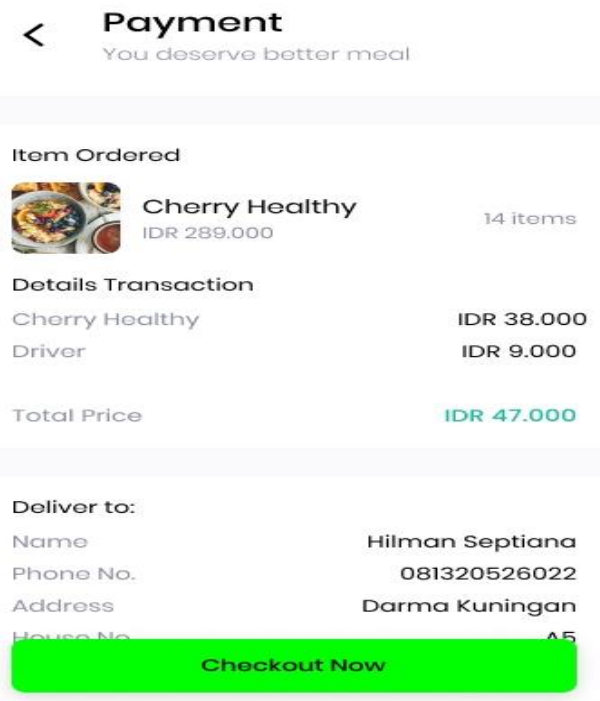

Gambar 15.Halaman Pemesanan

Halaman ini merupakan pemesanan yang dilakukan pembeli setelah memilih menu di halaman home. Pemesanan akan dikirimkan oleh kurir dengan pembayaran cash on Delivery.

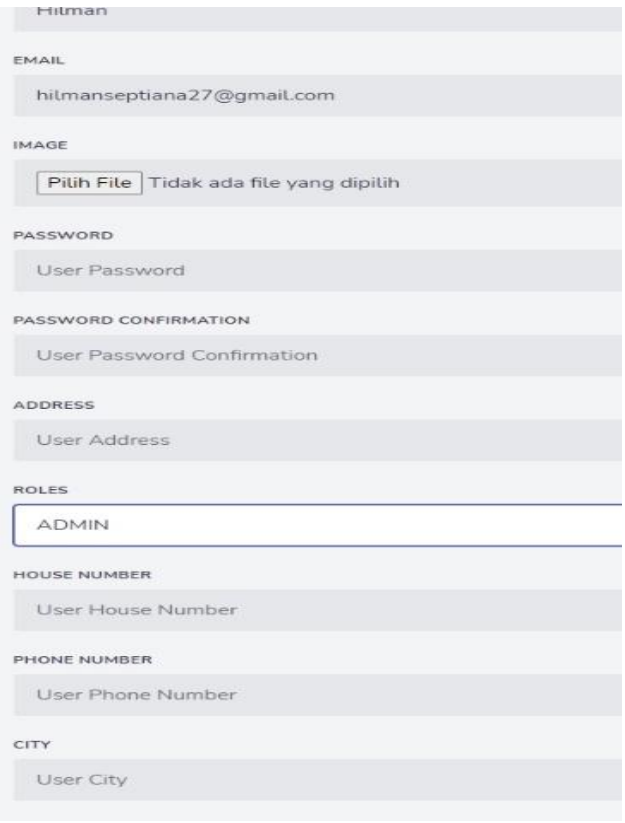

Gambar 16. Halaman Manejemen user

Pada Halaman ini admin dapat mengolah data pembeli jika ada kendala atau kesalahan pada saat user input data di awal pendaftaran

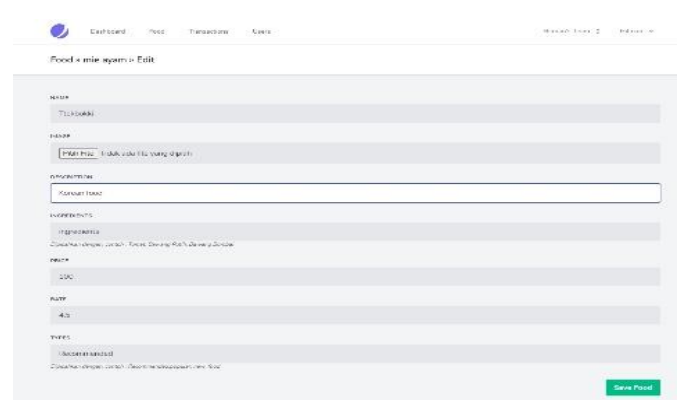

Gambar 17. Halaman Mananjemen Food

Halaman ini admin dapat mengolah data makanan bisa menambahkan atau pun memperbaharui dan menghapus makanan.

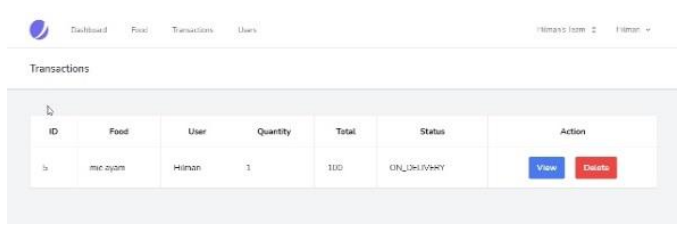

Gambar 18. Halaman Manajemen Transaksi

Halaman ini berisi pemesanan yang sedang aktif dan admin dapat mengolah data transaksi untuk mengubah status pemesanan pembeli. 


\subsection{Testing (Pengujian)}

\subsubsection{Pengujian halaman daftar}

Pengujian yang dilakukan pada halaman ini dengan cara menguji masing-masing textbox yang terdapat pada form pendaftaran yaitu nama lengkap, alamat, email, no hp, no rumah dan kota. Berikut adalah hasil pengujian halaman pendaftaran:

Tabel 1: Pengujian blackbox halaman pendaftaran

\begin{tabular}{|c|c|c|c|c|}
\hline No & $\begin{array}{c}\text { Rancangan } \\
\text { Proses }\end{array}$ & $\begin{array}{c}\text { Hasil yang } \\
\text { diharapka } \\
n\end{array}$ & Hasil & Ket \\
\hline 1 & $\begin{array}{l}\text { Mengisi data } \\
\text { calon } \\
\text { pembeli }\end{array}$ & $\begin{array}{l}\text { Data Calon } \\
\text { pembeli } \\
\text { tersimpan }\end{array}$ & sesuai & $\begin{array}{l}\text { Jika } \\
\text { semua } \\
\text { textbox } \\
\text { diisi } \\
\text { dengan } \\
\text { lengka } \\
\mathrm{p}\end{array}$ \\
\hline 2 & $\begin{array}{l}\text { Mengisi data } \\
\text { calon } \\
\text { pembeli } \\
\text { tidak } \\
\text { lengkap }\end{array}$ & $\begin{array}{l}\text { System } \\
\text { akan } \\
\text { memberika } \\
\text { n pesan } \\
\text { "Data tidak } \\
\text { boleh } \\
\text { kosong }\end{array}$ & Sesuai & \\
\hline 3 & $\begin{array}{l}\text { Nomor } \\
\text { handphone } \\
\text { hanya bisa } \\
\text { diinput } \\
\text { dengan } \\
\text { angka 0-9 }\end{array}$ & $\begin{array}{l}\text { Jika diiput } \\
\text { selain } \\
\text { angka } \\
\text { textbox } \\
\text { tidak dapat } \\
\text { terisi }\end{array}$ & sesuai & \\
\hline 4 & $\begin{array}{l}\text { Validasi } \\
\text { Email jika } \\
\text { data yang } \\
\text { diiput tidak } \\
\text { sesuai } \\
\text { format }\end{array}$ & $\begin{array}{l}\text { System } \\
\text { akan } \\
\text { memberika } \\
\text { n sesuai } \\
\text { pesan } \\
\text { "Email } \\
\text { tidak valid" }\end{array}$ & sesuai & \\
\hline
\end{tabular}

\subsubsection{Pengujian halaman login pembeli}

Pengujian pada halaman ini dilakukan untuk memvalidasi email dan password apakah berjalan sesuai dengan fungsinya. Berikut adalah hasil pengujian halaman login calon pembeli:

\begin{tabular}{|l|l|l|l|l|}
\hline No & $\begin{array}{c}\text { Rancanga } \\
\text { n Proses }\end{array}$ & $\begin{array}{c}\text { Hasil yang } \\
\text { diharapkan }\end{array}$ & Hasil & Ket \\
\hline 1 & Masukan & Masuk ke & sesuai & \\
& Email dan & halaman & & \\
& Password & home & & \\
& dengan & Untuk & & \\
& lengkap & memesan & & \\
& lalu klik & pilihan & & \\
& login & makanan & & \\
\hline 2 & Email dan & Sistem akan & Sesuai & \\
\hline
\end{tabular}

\begin{tabular}{|l|l|l|l|l|}
\hline & $\begin{array}{l}\text { password } \\
\text { dimasukan }\end{array}$ & $\begin{array}{l}\text { memberikan } \\
\text { pesan }\end{array}$ & & \\
& salah lalu & "Eamil atau & & \\
& klik & Password & & \\
masuk. & anda salah" & & \\
\hline 3 & Email atau & Sistem & Sesuai & \\
& password & memberikan & & \\
& dikosongk & pesan & & \\
& an lalu & "kolom & & \\
& klik & tidak boleh & & \\
& masuk & kosong' & & \\
\hline
\end{tabular}

\subsubsection{Pengujian halaman login admin.}

Pengujian pada halaman ini dilakukan pada funsgi validasi email dan password, apakah berjalan sesuai dengan fungsinya. Berikut adalah hasil pengujian halaman login administrator:

\begin{tabular}{|l|l|l|l|l|}
\hline No & $\begin{array}{l}\text { Rancanga } \\
\text { n Proses }\end{array}$ & $\begin{array}{l}\text { Hasil yang } \\
\text { diharapka } \\
\text { n }\end{array}$ & Hasil & Ket \\
\hline 1 & $\begin{array}{l}\text { Masukan } \\
\text { Email dan } \\
\text { password } \\
\text { lengkap } \\
\text { lalu klik } \\
\text { masuk }\end{array}$ & $\begin{array}{l}\text { Masuk ke } \\
\text { halamanad } \\
\text { ministrator }\end{array}$ & Sesuai & \\
\hline 2 & $\begin{array}{l}\text { Email dan } \\
\text { password } \\
\text { dimasukan } \\
\text { salah lalu } \\
\text { klik } \\
\text { masuk. }\end{array}$ & $\begin{array}{l}\text { Pesan } \\
\text { "Something } \\
\text { Wrong" }\end{array}$ & Sesuai & \\
\hline 3 & $\begin{array}{l}\text { Email dan } \\
\text { Password }\end{array}$ & $\begin{array}{l}\text { Sistem } \\
\text { memberika } \\
\text { n Pesan “ } \\
\text { Harap isi } \\
\text { Bidang ini" }\end{array}$ & Sesuai & \\
& & & \\
\end{tabular}

\subsubsection{Pengujian Halaman input makanan}

Pengujian dilakukan pada halaman ini dengan cara menguji masing-masing textbox. Berikut adalah hasil pengujian halaman input makanan:

Tabel 4. Pengujian blackbox halaman input makanan

\begin{tabular}{|c|l|l|l|l|}
\hline No & $\begin{array}{c}\text { Rancan } \\
\text { gan } \\
\text { Proses }\end{array}$ & $\begin{array}{l}\text { Hasil yang } \\
\text { diharapkan }\end{array}$ & Hasil & Ket \\
\hline 1 & $\begin{array}{l}\text { Masukan } \\
\text { data } \\
\text { makanan } \\
\text { sesuai } \\
\text { dengan } \\
\text { data } \\
\text { form } \\
\text { yang di } \\
\text { sediakan }\end{array}$ & $\begin{array}{l}\text { Data } \\
\text { disimpan } \\
\text { kedalam } \\
\text { basis data. }\end{array}$ & Sesuai & \\
& & & \\
\hline 2 & Semua & Sistem & & \\
\hline
\end{tabular}




\begin{tabular}{|c|c|c|c|}
\hline & $\begin{array}{l}\text { textbox } \\
\text { dikosong } \\
\text { kan lalu } \\
\text { klik save } \\
\text { food }\end{array}$ & $\begin{array}{l}\text { memberikan } \\
\text { pesan } \\
\text { notifikasi } \\
\text { "semua } \\
\text { bidang } \\
\text { harap di isi" }\end{array}$ & \\
\hline 3 & $\begin{array}{l}\text { Salah } \\
\text { satu atau } \\
\text { beberapa } \\
\text { textbox } \\
\text { tidak di } \\
\text { isi lalu } \\
\text { klik save } \\
\text { food }\end{array}$ & $\begin{array}{l}\text { Sistem } \\
\text { memberikan } \\
\text { pesan } \\
\text { notifikasi } \\
\text { "Bidang } \\
\text { belum } \\
\text { terisi" }\end{array}$ & Sesuai \\
\hline
\end{tabular}

\subsection{Software Increment}

Setelah dilakukan implementasi sistem aplikasi Food market kemudian dilakukan kegiatan monitoring dan evaluasi terhadap sistem yang diterapkan, untuk kemudian dilakukan memperbaharui terhadap aplikasi Food market. Setelah dilakukan monitoring dan evaluasi maka untuk pengembangan sistem selanjutnya, sistem ini akan dikembangkan dengan membuat sistem informasi Food market yang mencakup data dan informasi terkait penjualan makanan dimulai dari informasi cetak data laporan, sistem maps, sistem pembayaran deposit saldo sampai dengan pencetakan surat keterangan.

\section{KESIMPULAN}

Berdasarkan hasil penelitian yang telah dilakukan ditemukan bahwa aplikasi Food market dapat memberikan kemudahan kepada masyarakat calon pembeli untuk mendapatkan informasi terkait

makanan yang di jual oleh bonjuk launchbox cafe, memudahkan dalam melakukan pemesanan dan pembelian. Metode Extreme Programming (XP) dapat digunakan untuk membangun atau mengembangkan perangkat lunak. Agar aplikasi ini berjalan sesuai dengan fungsinya oleh karena itu perlu dibuatkan berupa petunjuk teknis penggunaan. Untuk penelitian berikutnya untuk mengetahui apakah aplikasi ini sudah diterima di masyarakat dan memberikan kepuasan terhadap pengguna maka perlu dilakukannya evaluasi dengan menggunakan metode yang ada.'

\section{DAFTAR PUSTAKA}

[1] Gumelar, T., Astuti, R., \& Sunarni, A. T. (2017). Sistem Penjualan Online Dengan Metode. Jurnal Telematika mikom, vol. 9,no. 2, pp. 87-90.

[2] Prabowo, Sholiq, Ariyanto, S., \& Muqtadiroh, F. A. (2013). Rancang bangun aplikasi web informasi eksekutif pada pemerintah kabupaten XYZ. jurnal Teknik Pomits, Vol. 2 No.3. hh. A-476 A-480.

[3] Carolina, I., \& Rusman, A. (2019). Penerapan Extreme Programming Pada Sistem Informasi Penjualan Pakaian Berbasis Web (Studi Kasus Toko ST Jaya. JURNAL INOVTEK POLBENG, ol. 4, no. 2, p. 157.

[4] Gunawan, R. D., Oktavia, T., \& Borman, R. I. (2018). Perancangan Sistem Informasi Beasiswa Program Indonesia Pintar (PIP) Berbasis Online (Tudi Kasus: SMA N 1 Kota Bumi. Jurnal Mikrotik, vol. 8, no. 1, pp. 43-54.

[5] Melinda, M., Borman, R. I., \& Susanto, E. R. (2018). Rancang Bangun Sistem Informasi Publik Berbasis Web (Studi Kasus: Desa Durian Kecamatan Padang Cermin Kabupaten Pesawaran. Jurnal Tekno Kompak, vol. 11, no. 1, p. 1.

[6] Cholifah, W. N., Yulianingsih, \& Sagita, S. M. (2018). Pengujian Black Box Testing Pada Aplikasi Action \& Strategy Berbasis Android Dengan Teknologi Phonegap. Jurnal String, vol. 3, no. 2, pp. 206-210. 